\title{
The disruption of circadian clockwork in differentiating cells from rat reproductive tissues as identified by in vitro real-time monitoring system
}

\author{
Pei-Jian He, Masami Hirata, Nobuhiko Yamauchi, Seiichi Hashimoto ${ }^{1}$ and Masa-aki Hattori \\ Laboratory of Reproductive Physiology and Biotechnology, Department of Animal and Marine Bioresource Sciences, Graduate School of Agriculture, Kyushu \\ University, 6-10-1 Hakozaki, Higashi-ku, Fukuoka 812-8581, Japan \\ ${ }^{1}$ Molecular Medicine Research Labs, Drug Discovery Research, Astellas Pharma Inc., Miyukigaoka 21, Tsukuba-shi, Ibaraki 305-8585, Japan \\ (Requests for offprints should be addressed to M-a Hattori; Email: mhattori@agr.kyushu-u.ac.jp)
}

\begin{abstract}
The circadian clock, regulating hormonal secretion and metabolisms in accordance with the environmental light-dark cycle, resides in almost all peripheral tissues as well as in the superchiasmatic nucleus. Clock gene expression has been found to be noncyclic during spermatogenesis and the differentiation of thymocytes. However, currently little is known about how cell differentiation could affect circadian clockwork. We performed this study using the in vitro realtime oscillation monitoring system to examine the clockwork in several types of differentiating cells originated from reproductive tissues of transgenic rats (constructed with Period gene 2 (Per2) promoter-destabilized luciferase reporter gene). After treatment with dexamethasone (DXM), persistent oscillation of Per2 expression was observed in both gonadotropin-induced and pregnant ovarian luteal cells,
\end{abstract}

proliferative uterine stromal cells (USCs), and nondifferentiating testicular interstitial cells, with a cyclic period of $\sim 24 \mathrm{~h}$. In contrast to these cell types, only one cycle of oscillation was sustained in granulosa cells undergoing differentiation. Additionally, Per2 oscillation was irregular in USCs undergoing decidualization induced by medroxyprogesterone acetate plus N6, 2-O-dibutyryl adenosine $3^{\prime}: 5^{\prime}$ cyclic monophosphate. Furthermore, no oscillation of Per2 expression was evoked by DXM in Leydig cells and thymocytes. In conclusion, the present study characterized the oscillation of Per2 gene expression in several types of ovarian, uterine, and testicular cells, and it is strongly suggested that circadian clockwork is affected during cellular differentiation.

Journal of Endocrinology (2007) 193, 413-420

\section{Introduction}

The circadian clock is primarily synchronized with environmental time by the $12 \mathrm{~h}$ light: $12 \mathrm{~h}$ darkness cycle (Reppert \& Weaver 2001). In mammals, the time-keeping system is composed of a central clock in the superchiasmatic nucleus that coordinates the subsidiary oscillators in extensive peripheral tissues (Reppert \& Weaver 2001, Schibler \& Sassone-Corsi 2002, Yamamoto et al. 2004). At molecular level, the clock system is composed of interlocked transcriptional and translational feedback loops. The CLOCK and BMAL1 (brain and muscle aryl hydrocarbon receptor nuclear translocator-like protein 1), associated as heterodimers, bind to the E-box enhancer element and positively drive the expression of Period genes (Per1, Per2, and Per3) and Cryptochrome genes (Cry1 and Cry2), whose proteins, in turn, form multimeric complexes and feed back to repress the transactivation by CLOCK/BMAL1 in the nucleus (Shearman et al. 2000, Ueda et al. 2005). Furthermore, post-translational processes involving the phosphorylation and degradation of proteins, and regulated nuclear import and export, are crucial for sustaining the $\sim 24 \mathrm{~h}$ duration (Lee et al. 2001, Harms et al. 2004).

The peripheral clock plays an essential role in synchronizing local physiology to operate in a circadian manner via regulation of the expression of functional genes (Storch $e t$ al. 2002, Zvonic et al. 2006). These physiological processes mainly include hormonal secretion and metabolisms like gluconeogenesis and lipogenesis (Lemos et al. 2006, Wijnen \& Young 2006). Interestingly, cultured cell lines could also exhibit several cycles of oscillations of the clock genes when treated with dexamethasone (DXM), a serum shock or other potential stimuli (Balsalobre et al. 1998, 2000). However, it has been suggested that the circadian clock does not work in the thymic tissue (Alvarez \& Sehgal 2005) and during murine spermatogenesis (Alvarez et al. 2003, Morse et al. 2003). Alvarez et al. proposed that cellular differentiation might cause the suspension of the cyclic expression of clock genes. In addition, it has been reported that the DNA-binding activity of CLOCK/BMAL1 heterodimers is regulated by the redox state of NADH cofactors (Rutter et al. 2001). However, currently little is known about whether and how circadian 
clockwork could be affected by changes of cellular physiological state.

The mammalian reproductive tissues are characterized with ever-changing physiology. Ovarian granulosa cells (GCs) undergo proliferation and differentiation during folliculogenesis under the regulation of follicle-stimulating hormone and locally produced factors (Richards 1994). The uterus is another highly dynamic tissue. In rodents, the endometrial stromal cells undergo proliferation and decidualization in response to steroid hormones and blastocyst implantation at the early stage of pregnancy (Dey et al. 2004). In the mammalian testicular and thymus tissues, the interstitial Leydig cells and the thymocytes ( $T$ lymphocytes) both undergo sequential stage-wise cellular differentiation (Touraine et al. 1977, Penit \& Vasseur 1988, Mendis-Handagama \& Ariyaratne 2001). The in vitro realtime oscillation monitoring system is a valuable tool for the investigation of circadian clockwork in cultured cell lines (Fujioka et al. 2006, Nakahata et al. 2006). In the present study, the real-time monitoring system was employed to evaluate the clockwork in several types of differentiating cells originated from the reproductive tissues of transgenic rats that have been constructed with Per2 promoter-destabilized luciferase reporter gene.

\section{Materials and Methods}

\section{Chemicals}

Dulbecco's modified Eagle's medium (DMEM)/F12, fetal bovine serum (FBS), and $100 \times$ penicillin-streptomycin solution (PS) were purchased from GIBCO; diethylstilbestrol (DES), trypsin, trypan blue, EGTA, medroxyprogesterone acetate (MPA), N6, 2-O-dibutyryl adenosine $3^{\prime}: 5^{\prime}$-cyclic monophosphate (db-cAMP), and luciferin were from Sigma. Collagenase was purchased from Invitrogen. DNase I was from Roche Diagnostics. Equine and human chorionic gonadotropin (eCG and hCG) were obtained from Teikoku Hormone Mfg. Co. (Tokyo, Japan).

\section{Animals}

Mouse Per2 promoter region (chr1 (-): 93289505-93293019 on the Build 36 'essentially complete' assembly by National Center for Biotechnology Information and the Mouse Genome Sequencing Consortium), which is sufficient for circadian oscillation, was fused to a destabilized luciferase $(d L u c)$ reporter gene $(d L u c$; luciferase gene fused with modified PEST sequence; Ueda et al. 2002). Per2-dLuc transgenic rats were generated in accordance with the method described in the patent publication number WO/2002/081682 (Y S New Technology Institute, Utsunomiya, Japan). Transgenic rats were maintained under $12 \mathrm{~h}$ light: $12 \mathrm{~h}$ darkness cycle (light between 0800 and 2000) with water and food ad libitum. Adult females were mated with fertile males to produce pregnant rats for isolation of endometrial stromal cells. The day of finding a copulatory plug or sperm in the vaginal smear was designated as day 1 of pregnancy. All the experiments were performed under the control of the Guideline for Animal Experiment in Faculty of Medicine, Kyushu University and The Law (no. 105) and Notification (no. 6) of the Government.

\section{Preparation and culture of cells}

GCs were prepared as previously described (Hattori et al. 1996) with minor modifications. Briefly, immature female rats at 21-23 days of age were injected subcutaneously with DES ( $1 \mathrm{mg} /$ day) for 3 days. Ovaries were collected, incubated in DMEM/F-12 containing $6 \mathrm{mM}$ EGTA for $15-30 \mathrm{~min}$, and then in DMEM/F-12 supplemented with $0.5 \mathrm{M}$ sucrose for $10-20 \mathrm{~min}$ at $37^{\circ} \mathrm{C}$. GCs were harvested by penetration of the follicles with a 27 gauge needle. The released cells were washed thrice with fresh medium. Approximately, $1 \times 10^{6}$ GCs were plated on a $35 \mathrm{~mm}$ collagen-coated dish with $2 \mathrm{ml}$ culture medium (DMEM/F12 supplemented with $1 \times$ PS and $10 \% \mathrm{FBS})$.

Luteal cells (LCs) were prepared according to a previous report (Peluso et al. 2005) with slight modifications. Briefly, immature rats were treated with $50 \mathrm{IU}$ eCG and $25 \mathrm{IU}$ hCG $60 \mathrm{~h}$ later. Ovaries were collected on day 4 after hCG injection, followed by incubation in PBS containing $0 \cdot 25 \%$ trypsin and $1 \mathrm{mM}$ EGTA for $15 \mathrm{~min}$ at $37^{\circ} \mathrm{C}$. For comparison, ovaries were also isolated from the rats at day 5 of pregnancy. The corpora lutea were teased away from the connective tissues and incubated with PBS supplemented with $0 \cdot 2 \%$ collagenase, $30 \mu \mathrm{g} / \mathrm{ml}$ DNase I and $0.5 \%$ BSA for $1 \mathrm{~h}$ at $37^{\circ} \mathrm{C}$. Cells were washed, and then plated on $35 \mathrm{~mm}$ collagen-coated dishes at the density of $1 \times 10^{6}$ cells/dish in $2 \mathrm{ml}$ culture medium. More than $90 \%$ cells were positive to $3 \beta$-hydroxysteroid dehydrogenase ( $3 \beta-\mathrm{HSD})$ staining.

Uterine stromal cells (USCs) were isolated from uterine horns of the rats at the stage of day 5 gestation. The uterine lumens were filled with PBS containing $0 \cdot 1 \%$ collagenase and incubated at $37^{\circ} \mathrm{C}$ for $1 \mathrm{~h}$ in a shaking water bath. The dissociated cells were washed and seeded at the density of $2 \times 10^{5}$ cells/dish. The culture medium was replaced at $15 \mathrm{~min}$ after cell seeding to remove epithelial cells. In vitro decidualization of USCs was performed as previously described (Matsui et al. 2004). Confluent USCs were further cultured for 6 days in DMEM/F12 supplemented with $2 \%$ FBS, $0.1 \mathrm{mM}$ MPA, and $0.5 \mathrm{mM}$ db-cAMP, with each medium changed every 3 days.

Testicular interstitial cells (TICs) were separated from decapsulated testes of the rats aged 2 months by collagenase digestion (Niedziela \& Lerchl 1999). The dispersed cells were plated on collagen-coated dishes. After $1 \mathrm{~h}$, the suspended cells were removed from adhesive TICs and subjected to the isolation of pure Leydig cells by Percoll density gradient centrifugation (Niedziela \& Lerchl 1999). The Leydig cell fraction was collected, completely washed, and seeded on collagen-coated dishes at the density of $1 \times 10^{6}$ cells/dish. 
After 24 -h culture at $37{ }^{\circ} \mathrm{C}, 3 \beta$-HSD staining was performed on both Leydig cells and adhesive TICs, with $80-90 \%$ of the cells positively stained within the former population and $>$ $90 \%$ of the cells unstained for the latter. Approximately, 85$90 \%$ of the Leydig cells were viable as revealed by trypan blue staining.

Thymocytes were prepared from thymus tissues of 2-month old male rats as previously reported (Oka et al. 2000). Harvested cells were dispersed in culture medium and plated on collagen-coated dishes at the density of $1 \times 10^{6}$ cells/dish. After $1 \mathrm{~h}$ of cell seeding, the suspended cells were transferred into new dishes to remove the contamination by adhesive cells such as fibroblast cells and macrophages.

All the cultures were performed in a humidified atmosphere of $95 \%$ air and $5 \% \mathrm{CO}_{2}$ at $37^{\circ} \mathrm{C}$ until the bioluminescent monitoring with Kronos AB-2500 (ATTO, Tokyo, Japan) and the isolation of total RNA.

\section{RT-PCR}

Cultured cells were harvested at the indicated times and total RNA was extracted using Sepasol reagent according to the manufacturer's protocol. Total RNA $(1 \mu \mathrm{g})$ was then used for cDNA synthesis in $20 \mu \mathrm{l}$ mixture. The expression levels of $\beta$-actin, luteinizing hormone receptor (LHR), and decidual/trophoblast prolactin-related protein $(\mathrm{d} / \mathrm{t}$ PRP) were examined by PCR using the following primers: $\beta$-actin (NM_031144), F: 5'-TTG CGC TCA GGA GGA GCA AT - $3^{\prime}$, R: $5^{\prime}$-ATC ATG TTT GAG ACC TTC AA-3'; LHR (NM_012978), F: $5^{\prime}$-AGG GAT GAA TAA CGA GTC TGT C- $3^{\prime}, \mathrm{R}: 5^{\prime}$-ATT GGA GTG TCT TGG GTG AAC $-3^{\prime} ;$ d/t PRP (NM_022846), F: 5'-ATC CAG CGA GCT GAA GTC AT-3', R: 5'-CAT GAA GTG GTG GGT TTG TG-3'. PCR was performed in a $10 \mu \mathrm{l}$ mixture containing $1 \times$ PCR buffer, $0 \cdot 25 \mathrm{U}$ AmpiTaq-Gold enzyme, $0 \cdot 2 \mathrm{mM}$ of each dNTP, $1.5 \mathrm{mM} \mathrm{MgCl}_{2}, 0 \cdot 2 \mu \mathrm{M}$ of each primer, and $1 \mu \mathrm{l}$ of each RT product (after $5 \times$ dilution) as a template. Amplification was performed in a programmable thermocycler (Biometra, Germany). The following cycling conditions were applied, denaturing at $95^{\circ} \mathrm{C}$ for $50 \mathrm{~s}$, annealing at $50^{\circ} \mathrm{C}$ for $50 \mathrm{~s}$, and extension at $72{ }^{\circ} \mathrm{C}$ for $50 \mathrm{~s}$ ( 28 cycles). The PCR products were subjected to agarose (2\%) electrophoresis. The bands, stained by ethidium bromide, were visualized by u.v. fluorescence. Densitometric analysis was performed using Scion Image (NIH software).

\section{Real-time monitoring of bioluminescence}

Cultured cells were treated with $0 \cdot 1 \mu \mathrm{M}$ DXM in serum-free medium. After $2 \mathrm{~h}$, the medium was replaced with $2 \mathrm{ml}$ DMEM/F12 containing 5\% FBS, $1 \times$ PS, 15 mM HEPES, and $0.1 \mathrm{mM}$ luciferin. Real-time monitoring of bioluminescence was performed at $37^{\circ} \mathrm{C}\left(34^{\circ} \mathrm{C}\right.$ for Leydig cells) using Kronos AB-2500 interfaced to computer for continuous data acquisition as previously described ( $\mathrm{He}$ et al. 2006). The photon counts were integrated for $1 \mathrm{~min}$ at intervals of $8 \mathrm{~min}$.
Data analysis

Period was calculated as previously reported (Abe et al. 2002). The original data were smoothed by an adjacent averaging method with $3 \mathrm{~h}$ running means. The peak and trough were calculated as the highest and lowest point of smoothed data respectively. The time of trough was used as the phase marker for analysis of cycle period. The data are expressed as mean \pm S.D. $(n=6)$ and the differences between them were evaluated using Student's $t$-test following one-way ANOVA. $P<0 \cdot 05$ was considered significant.

\section{Results}

LCs display more stable oscillation of Per2 expression than differentiating GCs

The $48 \mathrm{~h}$ cultured GCs and LCs were treated with DXM for $2 \mathrm{~h}$ and subjected to real-time monitoring of Per2 oscillation. In both GCs and LCs, a peak of Per2 expression was found at about $4 \mathrm{~h}$ after the initiation of monitoring. Whilst circadian oscillation of Per2 was induced in both cell types, the oscillatory pattern was distinct between GCs and LCs. Only one cycle of oscillation was apparently sustained in GCs during $96 \mathrm{~h}$ monitoring (Fig. 1A). In contrast, persistent oscillation was observed in LCs, albeit with a continuous decreasing of amplitude (Fig. 1B). Furthermore, persistent Per2 oscillation was also observed in the LCs isolated from the rat ovaries on day 5 of pregnancy (Fig. 1C).

The differentiating status of cultured GCs was examined by the expression of LHR, a classical marker of GC differentiation. The $48 \mathrm{~h}$ cultured GCs, after exposure to DXM for $2 \mathrm{~h}$, were collected at $4 \mathrm{~h}$ intervals within $48 \mathrm{~h}$ and subjected to RNA extraction and RT-PCR analysis of $L H R$ expression. The result showed that $L H R$ expression was present at time $0 \mathrm{~h}$ and reached an expression platform from $24 \mathrm{~h}$ onward in the DXM-treated GCs (Fig. 2).

\section{Unstable Per2 oscillation is not due to GCs death}

Given that GCs could spontaneously undergo cellular apoptosis in culture (Tilly et al. 1992), we explored whether cell death is responsible for the nonpersistent Per2 oscillation in GCs. After $48 \mathrm{~h}$ monitoring, the medium was replaced with fresh medium or medium supplemented with $10 \mu \mathrm{M}$ forskolin and GCs were subjected to continued detection. Another cycle of robust oscillation was induced by a simple medium change (Fig. 3A). Forskolin administration evoked a pattern of Per2 oscillation mimicking that induced by DXM (Fig. 3B). Furthermore, after 48-h bioluminescent detection, GCs were detached and cell viability was directly examined by trypan blue staining. The result revealed that $\sim 90 \%$ of the cells were viable (data not shown). Consequently, it is unlikely that cell death caused the cessation of Per2 oscillation in GCs after only one cycle. 

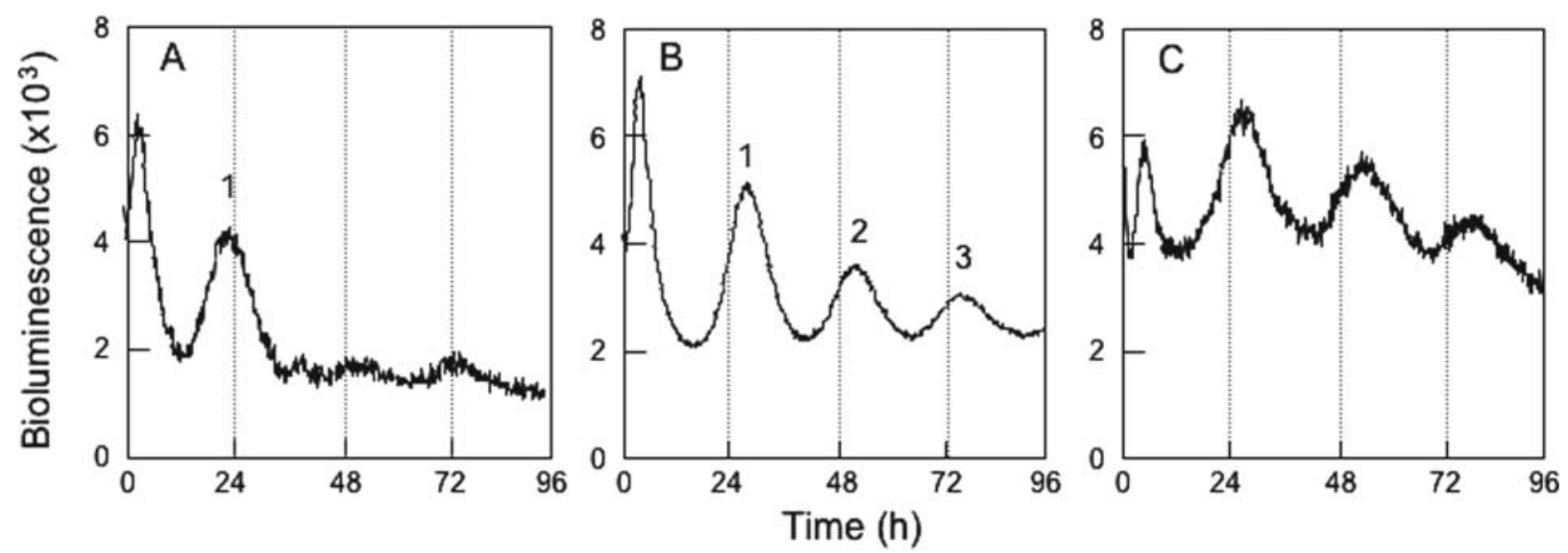

Figure 1 Circadian oscillations of Per 2 expression in GCs and LCs. GCs and LCs were cultured for $48 \mathrm{~h}$, and exposed to DXM (0.1 $\mu \mathrm{M})$ for $2 \mathrm{~h}$ prior to the real-time monitoring of bioluminescence. Representative graphs show Per2 oscillation in (A) GCs, (B) eCG/hCG-induced LCs, and (C) pregnant LCs. Each experiment was independently performed six times for (A) and (B) and thrice for (C). Numbers show the oscillatory cycles.

Per2 oscillation is irregular in USCs undergoing decidualization

USCs were cultured for 3 days to reach confluence and subjected to DXM treatment and real-time monitoring of Per2 expression. The USCs displayed similar pattern of oscillation to that obtained in LCs within 96-h detection (Fig. 4A). The decidualization of USCs was induced by MPA and db-cAMP, and the differentiating status was revealed by the strong expression of $d t / P R P$ gene (Fig. 4B), a useful marker of decidualization ( $\mathrm{Gu}$ et al. 1994). The subsequent bioluminescent monitoring showed distinct pattern of Per2 expression in decidualizing USCs from that in nontreated USCs. After DXM treatment, a visible peak of Per2 expression was observed at about $29 \mathrm{~h}$, however, followed by a prolonged falling phase

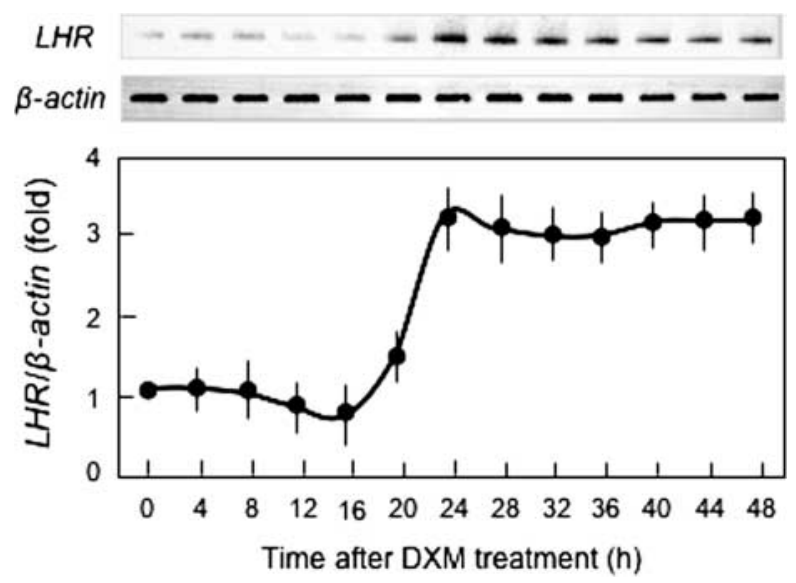

Figure 2 The expression of $L H R$ in GCs after DXM treatment. The 48-h cultured GCs were treated with $0 \cdot 1 \mu \mathrm{M}$ DXM for $2 \mathrm{~h}$ and harvested at the indicated time points. Total RNA was isolated and subjected to RT-PCR analysis of the transcript level of LHR. $\beta$-actin was used as an internal control. Data represent the mean \pm s.D. of three independent experiments (basal set as 1). without obvious circadian or circadian-like oscillation (Fig. 4C).

No oscillation of Per2 expression is evoked in Leydig cells and thymocytes

Adhesive TICs were cultured for 3 days and Leydig cells were cultured for $24 \mathrm{~h}$ prior to DXM treatment and subsequent bioluminescent monitoring. LHR, a useful marker of Leydig cell differentiation (Siril Ariyaratne et al. 2000), was abundantly expressed in the Leydig cells but not in the adhesive TICs (Fig. 5A), which suggested the differentiating status of Leydig cells. Strikingly high amplitude of Per2 oscillation was observed for adhesive TICs (Fig. 5B). In contrast, no obvious oscillation of Per2 expression was evoked in Leydig cells by DXM (Fig. 5C). Further no significant oscillation was also observed in Leydig cells treated with forskolin (data not shown). The potential of clockwork in

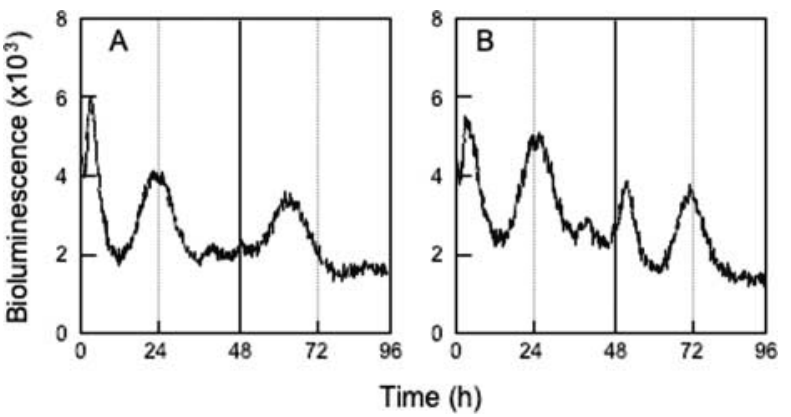

Figure 3 The oscillations of Per2 expression in GCs after medium changes. Medium changes were performed at $48 \mathrm{~h}$ (solid vertical line) after the initiation of bioluminescent monitoring. Graphs represent the oscillatory patterns of Per2 in GCs with a medium change of fresh DMEM/F12 (A) or DMEM/F12 containing $10 \mu \mathrm{M}$ forskolin (B). Each experiment was independently performed at least three times. 

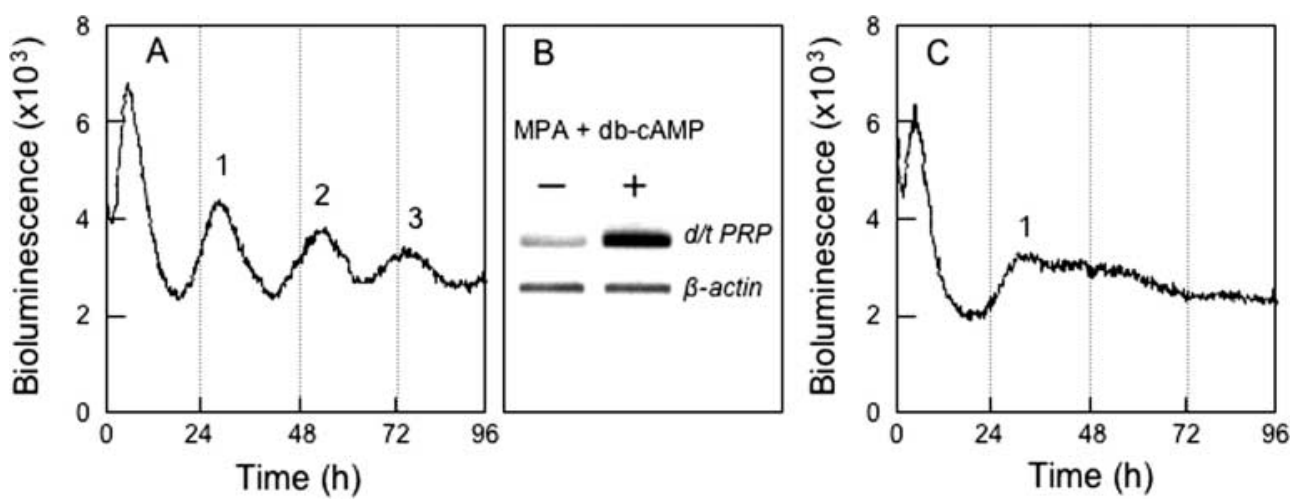

Figure 4 Oscillations of Per2 expression in proliferative and decidualizing USCs. Proliferative USCs were derived from the uterine horns on day 5 of pregnancy and cultured for 3 days prior to any treatment. Decidualizing cells were obtained by treating confluent USCs for 6 days with $0.1 \mathrm{mM}$ MPA plus $0.5 \mathrm{mM}$ db-cAMP. The mRNA level of $d t / P R P$, a marker for USCs decidualization, was analyzed by RT-PCR in treated and nontreated control (B). Both types of cells were likewise treated with DXM for $2 \mathrm{~h}$ prior to bioluminescent monitoring. Representative graphs show the oscillatory patterns of Per2 in proliferative (A) and decidualizing (C) USCs. Each experiment was independently performed six times and numbers show the oscillatory cycles.

differentiating thymocytes was also examined for comparison with that exhibited in Leydig cells. Thymocytes cultured for $24 \mathrm{~h}$ were likewise treated with DXM and subjected to the monitoring of Per2 expression. The thymocytes also did not exhibit any evidence of Per2 oscillation (Fig. 5D).

\section{Statistical analysis of the oscillations of Per2 in various cells}

The mean time of the first peak of Per2 oscillation in GCs appeared at $\sim 24 \mathrm{~h}$, which was significantly $(P<0 \cdot 05)$ earlier than that observed in other cell types (Table 1). The first peak time could not be calculated in Leydig cells and thymocytes due to the lack of any visible oscillation. The mean period length of each oscillatory cycle was $\sim 24 \mathrm{~h}$ in GCs, LCs, proliferative USCs, and adhesive TICs (Table 1). Determination of the cyclic period could not be made in differentiating USCs, Leydig cells, and thymocytes.

\section{Discussion}

In the present study, several types of cells, originated from the reproductive tissues of Per2- $d L u c$ transgenic rats, were employed to demonstrate whether and how circadian clockwork could be affected during cellular differentiation. Our results for the first time showed distinct pattern of Per2 oscillation in differentiating cells from that in proliferative or terminally differentiated cells.

In GCs, only one cycle of oscillation of Per2 expression was induced after exposure to DXM, with the peak appearing at $\sim 24 \mathrm{~h}$. In contrast, persistent Per2 oscillation was observed in both eCG/hCG-induced LCs and pregnant LCs. This distinctiveness is thought to be related with each cellular physiology. It has been suggested that GCs spontaneously undergo cellular apoptosis in culture (Tilly et al. 1992).
However, it is unlikely that cell death caused the cessation of Per 2 oscillation in GCs after only one cycle, as $90 \%$ of the cells were still viable, and another cycle of oscillation could be again evoked by replacement with fresh medium or stimulation with forskolin. This is consistent with a previous report (Yamazaki et al. 2000). Alternatively, GCs could potentially undergo cellular differentiation during in vitro culture, which is unlike LCs and is terminally differentiated. Indeed, $L H R$, a classical marker of GCs differentiation, was found to be abundantly expressed in cultured GCs from $24 \mathrm{~h}$ onward after DXM treatment. It is thus more likely that cell differentiation is responsible for the lack of persistent Per2 oscillation in GCs. We speculate that circadian clockwork in differentiating GCs might be highly susceptible to the changes of environmental conditions, e.g., $\mathrm{pH}$, depletion of nutrients, and accumulation of metabolic substances.

Several laboratories have focused on the expression of clock genes in the ovarian follicles and/or corpora lutea in vivo, but their findings were mostly conflicting. Studies on the circadian clock in the Drosophila ovary suggested that period and timelessness were constantly expressed in the follicular cells (Beaver et al. 2003). Fahrenkrug et al. (2006) reported the diurnal rhythm of Per1 and Per2 expression in the corpora lutea of rat ovaries. Conversely, Karman \& Tischkau (2006) reported that Bmal1 and Per2 were rhythmically expressed in the rat ovarian follicles but not in the corpora lutea. Our present findings to some extent suggest that, in vivo, circadian clockwork might be somewhat influenced in the follicular GCs during the process of cellular differentiation or maturation. By contrast, it is likely that a circadian clock operates more stably in the corpora lutea.

We further extended the studies on uterine cells to prove the possibility that cellular differentiation interferes with clockwork in differentiating cells. The USCs isolated from the uterus on day 5 of pregnancy are proliferative in culture. 

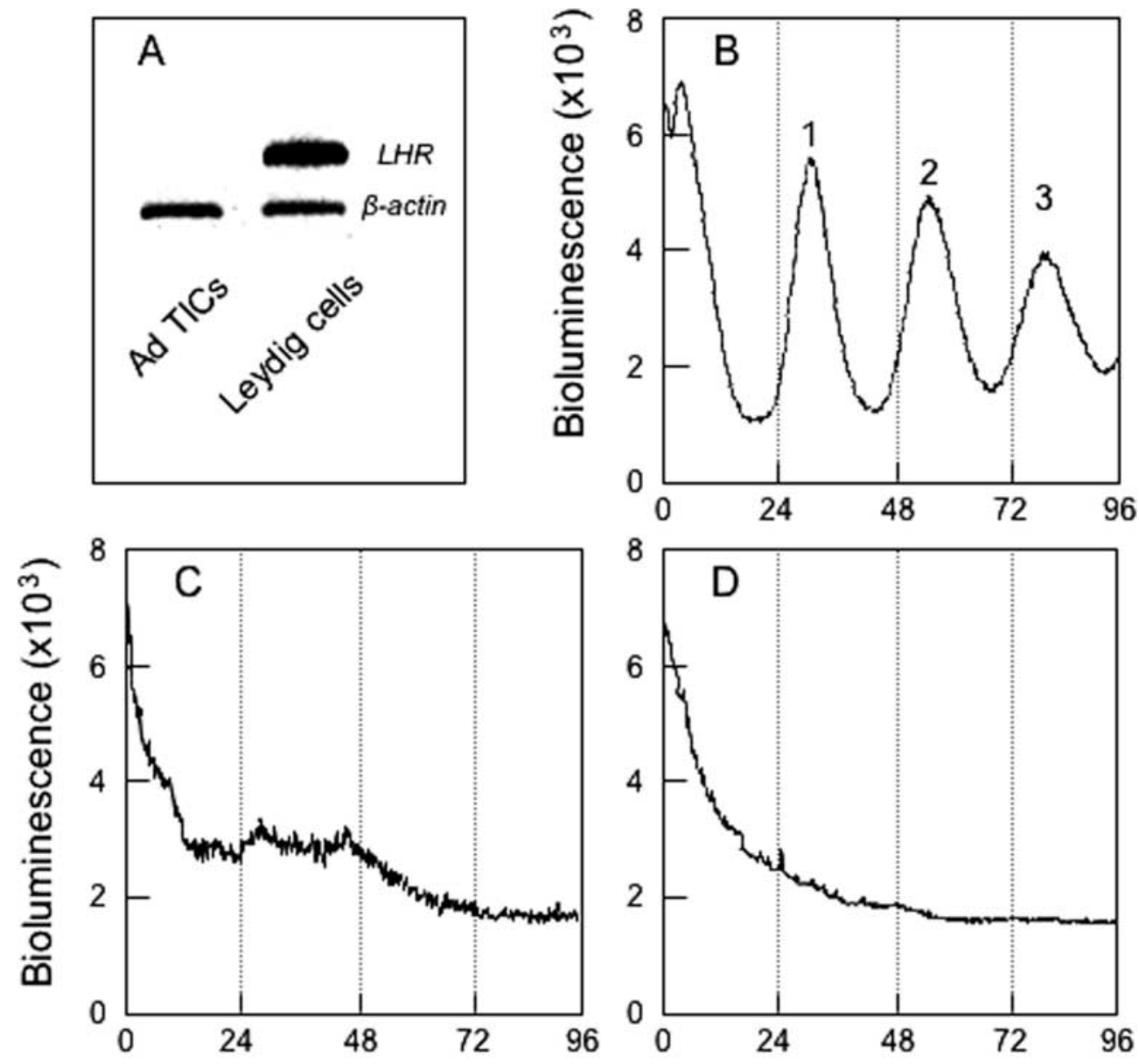

\section{Time (h)}

Figure 5 Representative expression patterns of Per2 in testicular interstitial cells and thymocytes. The expression of $L H R$ was examined in adhesive TICs and Leydig cells (A). Adhesive TICs (B), Leydig cells (C), and thymocytes (D) were treated with DXM for $2 \mathrm{~h}$, and Per2 expression was real-time monitored. Each experiment was independently performed six times. The numbers in $B$ show oscillatory cycles.

Decidualization of USCs was induced by MPA and db-cAMP (Matsui et al. 2004), and the strong expression of $d / t$ PRP indicated the differentiating status of USCs. Indeed, there was marked difference in the pattern of Per2 oscillation between proliferative and decidualizing USCs. Persistent Per2 oscillation observed in nontreated USCs disappeared in the latter, suggesting that normal clockwork might be disturbed during cellular differentiation. Previously, it has been reported that clock genes were rhythmically expressed in the rat uterus (Nakamura et al. 2005, Dolatshad et al. 2006). To the best of our knowledge, however, no report is available regarding whether the circadian clock is involved in the regulation of uterine stromal decidualization, which is critical for successful pregnancy in rodents ( $\mathrm{Gu}$ et al. 1994). The present finding predicts that, in vivo, the circadian rhythms in the endometrial stroma may be impaired during decidualization.
In vivo, cellular differentiation occurs in GCs and USCs only at a certain developmental stage i.e. later folliculogenesis and blastocyst attachment respectively. Herein, a circadian clockwork study was also performed in testicular Leydig cells and thymocytes, which are characterized with sequential stage-wise differentiation (Touraine et al. 1977, Penit \& Vasseur 1988, Mendis-Handagama \& Ariyaratne 2001). The presently prepared Leydig cell population may comprise Leydig cell lineage at different developmental stages (Mendis-Handagama \& Ariyaratne 2001). Remarkably, after exposure to potent resetting cues, no obvious synchronized Per2 oscillation could be observed in these differentiating Leydig cells, which is in dramatic contrast to the highamplitude of Per2 oscillation in the adhesive TIC population mainly consisting of nondifferentiating fibroblast-like (mesenchymal) cells, macrophages, and endothelial cells 
Table 1 Characterization of oscillation profiles of Per2 expression in various cell types

\begin{tabular}{|c|c|c|c|}
\hline \multirow{2}{*}{$\begin{array}{l}\text { First peak time }(\mathrm{h}) \\
(n=6)\end{array}$} & \multicolumn{3}{|c|}{ Cycle time $(h$, mean \pm s.D., $n=6)$} \\
\hline & 1 & 2 & 3 \\
\hline $23 \cdot 71 \pm 0 \cdot 35^{*}$ & $23 \cdot 45 \pm 0 \cdot 49$ & N.D. & N.D. \\
\hline $28 \cdot 24 \pm 0 \cdot 31$ & $23 \cdot 88 \pm 0 \cdot 41$ & $24 \cdot 26 \pm 0 \cdot 27$ & $24 \cdot 13 \pm 0 \cdot 22$ \\
\hline $28 \cdot 57 \pm 0 \cdot 39$ & $23 \cdot 63 \pm 0 \cdot 37$ & $23 \cdot 95 \pm 0.32$ & $24 \cdot 02 \pm 0 \cdot 43$ \\
\hline $28 \cdot 92 \pm 0.52$ & N.D. & N.D. & N.D. \\
\hline $29 \cdot 50 \pm 0 \cdot 36$ & $24 \cdot 45 \pm 0 \cdot 24$ & $24 \cdot 25 \pm 0 \cdot 46$ & $24 \cdot 13 \pm 0 \cdot 35$ \\
\hline N.D. & N.D. & N.D. & N.D. \\
\hline N.D. & N.D. & N.D. & N.D. \\
\hline
\end{tabular}

Cycle numbers are as marked in Figs 1, 4 and 5. Luteal cells are those from eCG/hCG-primed ovaries. N.D., not detected; ${ }^{*} P<0 \cdot 05$ versus other cell types.

(Niedziela \& Lerchl 1999, Mendis-Handagama \& Ariyaratne 2001). The lack of Per 2 oscillation in Leydig cells is similar to what was observed in differentiating thymocytes, wherein clock gene expression has been previously demonstrated to be noncyclic by in vivo examinations (Alvarez \& Sehgal 2005). However, the secretion of testosterone from Leydig cells has long been known to have a low-amplitude of diurnal rhythm (Goodman et al. 1974, Mock et al. 1978). The underlying mechanism is not yet clear. Our findings suggest that this diurnal rhythm is less likely to be due to control by the local clock system in Leydig cells. Rather, the previously reported diurnal LH level (Albertsson-Wikland et al. 1997, Mitamura et al. 1999) might contribute to the regulation of the diurnal rhythm of testosterone production.

Although the present study identified a distinct manner of clockwork in differentiating cells, much work is still required to clearly elucidate the underlying mechanism. Two possible explanations are proposed. One is that regular interaction of clock proteins and chromosomal DNA is disrupted or impaired at the level of gene transcription due to the requirement of differentiation-specific gene transcription. A second possibility is that, during cellular differentiation, the post-translational modifications and subsequent nucleocytoplasmic shuttling of clock proteins (Lee et al. 2001, Harms et al. 2004) are affected by the physiological state. Notably, Yoo et al. (2004) suggested that transgenic constructs do not always produce robust/sustained oscillations in peripheral tissues as compared with knock-in constructs. Therefore, the employment of knock-in constructs may provide further insights into the circadian clockwork in differentiating Leydig cells and thymocytes. Furthermore, future study using the method of bioluminescence imaging of individual cell will help to elucidate whether the destroyed coordination among differentiating cells during purification and nonadhesive culture is responsible for the quick desynchronization of DXM-evoked Per2 oscillation in Leydig cells and thymocytes in vitro.

In conclusion, using in vitro bioluminescence monitoring system, we characterized the oscillation of Per2 gene expression in several types of cells prepared from Per2-dLuc transgenic rats. The results demonstrated that DXM-induced
Per2 expression in differentiating cells was in dramatic contrast to that in proliferating or terminally differentiated cells. We also found obviously different Per2 oscillations in the cells undergoing differentiation only at a certain developmental stages (GCs and USCs) compared with the cells that exhibit sequential stage-wise differentiation (Leydig cells and thymocytes). The present findings may increase our understanding of the coordination between the developmental clock and circadian clock in the regulation of development and physiology.

\section{Acknowledgements}

We are grateful to Dr Christopher Wood (Zhejian University, Hangzhou, China) for his critical reading of the manuscript. This research was supported in part by a Grant-in-Aid for Scientific Research from the Japan Society for the Promotion of Sciences (JSPS; 16380200 and 17658131; to M-A H). The authors declare that there is no conflict of interest that would prejudice the impartiality of this scientific work.

\section{References}

Abe M, Herzog ED, Yamazaki S, Straume M, Tei H, Sakaki Y, Menaker M \& Block GD 2002 Circadian rhythms in isolated brain regions. Journal of Neuroscience 22 350-356.

Albertsson-Wikland K, Rosberg S, Lannering B, Dunkel L, Selstam G \& Norjavaara E 1997 Twenty-four-hour profiles of luteinizing hormone, follicle-stimulating hormone, testosterone, and estradiol levels: a semilongitudinal study throughout puberty in healthy boys. Journal of Clinical Endocrinology and Metabolism 82 541-549.

Alvarez JD \& Sehgal A 2005 The thymus is similar to the testis in its pattern of circadian clock gene expression. Journal of Biological Rhythms 20 111-121.

Alvarez JD, Chen D, Storer E \& Sehgal A 2003 Non-cyclic and developmental stage-specific expression of circadian clock proteins during murine spermatogenesis. Biology of Reproduction 69 81-91.

Balsalobre A, Damiola F \& Schibler U 1998 A serum shock induces circadian gene expression in mammalian tissue culture cells. Cell 93 929-937.

Balsalobre A, Brown SA, Marcacci L, Tronche F, Kellendonk C, Reichardt HM, Schutz G \& Schibler U 2000 Resetting of circadian time in peripheral tissues by glucocorticoid signaling. Science $2892344-2347$. 
Beaver LM, Rush BL, Gvakharia BO \& Giebultowicz JM 2003 Noncircadian regulation and function of clock genes period and timeless in oogenesis of Drosophila melanogaster. Journal of Biological Rhythms 18 463-472.

Dey SK, Lim H, Das SK, Reese J, Paria BC, Daikoku T \& Wang H 2004 Molecular cues to implantation. Endocrine Reviews 25 341-373.

Dolatshad H, Campbell EA, O'Hara L, Maywood ES, Hastings MH \& Johnson MH 2006 Developmental and reproductive performance in circadian mutant mice. Human Reproduction 21 68-79.

Fahrenkrug J, Georg B, Hannibal J, Hindersson P \& Gras S 2006 Diurnal rhythmicity of the clock genes Per1 and Per2 in the rat ovary. Endocrinology 147 3769-3776.

Fujioka A, Takashima N \& Shigeyoshi Y 2006 Circadian rhythm generation in a glioma cell line. Biochemical and Biophysical Research Communications 346 169-174.

Goodman RL, Hotchkiss J, Karsch FJ \& Knobil E 1974 Diurnal variations in serum testosterone concentrations in the adult male rhesus monkey. Biology of Reproduction 11 624-630.

Gu Y, Soares MJ, Srivastava RK \& Gibori G 1994 Expression of decidual prolactin-related protein in the rat decidua. Endocrinology 135 1422-1427.

Harms E, Kivimae S, Young MW \& Saez L 2004 Posttranscriptional and posttranslational regulation of clock genes. Journal of Biological Rhythms 19 361-373.

Hattori M-A, Sakamoto K, Fujihara N \& Kojima I 1996 Nitric oxide: a modulator for the epidermal growth factor receptor expression in developing granulosa cells. American Journal of Physiology Cell Physiology 270 C812-C818.

He PJ, Fujimoto Y, Yamauchi N \& Hattori M-A 2006 Real-time monitoring of cAMP response element binding protein signaling in porcine granulosa cells modulated by ovarian factors. Molecular and Cellular Biochemistry 290 177-184.

Karman BN \& Tischkau SA 2006 Circadian clock gene expression in the ovary: effects of luteinizing hormone. Biology of Reproduction 75 624-632.

Lee C, Etchegaray JP, Cagampang FR, Loudon AS \& Reppert SM 2001 Posttranslational mechanisms regulate the mammalian circadian clock. Cell 107 855-867.

Lemos DR, Downs JL \& Urbanski HF 2006 Twenty-four-hour rhythmic gene expression in the rhesus macaque adrenal gland. Molecular Endocrinology 20 1164-1176.

Matsui N, Kawano Y, Nakamura S \& Miyakawa I 2004 Changes in vascular endothelial growth factor production associated with decidualization by human endometrial stromal cells in vitro. Acta Obstetricia et Gynecologica Scandinavica 83 138-143.

Mendis-Handagama SM \& Ariyaratne HB 2001 Differentiation of the adult Leydig cell population in the postnatal testis. Biology of Reproduction 65 660-671.

Mitamura R, Yano K, Suzuki N, Ito Y, Makita Y \& Okuno A 1999 Diurnal rhythms of luteinizing hormone, follicle-stimulating hormone, and testosterone secretion before the onset of male puberty. Journal of Clinical Endocrinology and Metabolism 84 29-37.

Mock EJ, Norton HW \& Frankel AI 1978 Daily rhythmicity of serum testosterone concentration in the male laboratory rat. Endocrinology 103 $1111-1121$

Morse D, Cermakian N, Brancorsini S, Parvinen M \& Sassone-Corsi P 2003 No circadian rhythms in testis: Period1 expression is clock independent and developmentally regulated in the mouse. Molecular Endocrinology 17 $141-151$.

Nakahata Y, Akashi M, Trcka D, Yasuda A \& Takumi T 2006 The in vitro realtime oscillation monitoring system identifies potential entrainment factors for circadian clocks. BMC Molecular Biology 75.

Nakamura TJ, Moriya T, Inoue S, Shimazoe T, Watanabe S, Ebihara S \& Shinohara K 2005 Estrogen differentially regulates expression of Per 1 and Per 2 genes between central and peripheral clocks and between reproductive and nonreproductive tissues in female rats. Journal of Neuroscience Research $\mathbf{8 2}$ 622-630.

Niedziela M \& Lerchl A 1999 Isolation method of Leydig cells from mature male Djungarian hamsters (Phodopus sungorus) and their steroidogenic activity in vitro. Andrologia 31 157-161.
Oka T, Hayashi K, Nakaoka Y, Ohtsuki Y \& Akagi T 2000 Differentiation of rat thymic myoid progenitor cell line established by coculture with human T-lymphotropic virus type-I producing human $\mathrm{T}$ cells. Cell and Tissue Research 300 119-127.

Peluso JJ, Pappalardo A, Losel R \& Wehling M 2005 Expression and function of PAIRBP1 within gonadotropin-primed immature rat ovaries: PAIRBP1 regulation of granulosa and luteal cell viability. Biology of Reproduction $\mathbf{7 3}$ 261-270.

Penit C \& Vasseur F 1988 Sequential events in thymocyte differentiation and thymus regeneration revealed by a combination of bromodeoxyuridine DNA labeling and antimitotic drug treatment. Journal of Immunology $\mathbf{1 4 0}$ 3315-3323.

Reppert SM \& Weaver DR 2001 Molecular analysis of mammalian circadian rhythms. Annual Review of Physiology 63 647-676.

Richards JS 1994 Hormonal control of gene expression in the ovary. Endocrine Reviews 15 725-751.

Rutter J, Reick M, Wu LC \& McKnight SL 2001 Regulation of clock and NPAS2 DNA binding by the redox state of NAD cofactors. Science $\mathbf{2 9 3}$ 510-514.

Schibler U \& Sassone-Corsi P 2002 A web of circadian pacemakers. Cell 111 919-922.

Shearman LP, Sriram S, Weaver DR, Maywood ES, Chaves I, Zheng B, Kume K, Lee CC, van der Horst GT, Hastings MH et al. 2000 Interacting molecular loops in the mammalian circadian clock. Science 288 1013-1019.

Siril Ariyaratne HB, Chamindrani Mendis-Handagama S, Buchanan Hales D \& Ian Mason J 2000 Studies on the onset of Leydig precursor cell differentiation in the prepubertal rat testis. Biology of Reproduction 63 165-171.

Storch KF, Lipan O, Leykin I, Viswanathan N, Davis FC, Wong WH \& Weitz CJ 2002 Extensive and divergent circadian gene expression in liver and heart. Nature $\mathbf{4 1 7} 78-83$.

Tilly JL, Billig H, Kowalski KI \& Hsueh AJ 1992 Epidermal growth factor and basic fibroblast growth factor suppress the spontaneous onset of apoptosis in cultured rat ovarian granulosa cells and follicles by a tyrosine kinasedependent mechanism. Molecular Endocrinology 6 1942-1950.

Touraine JL, Hadden JW \& Good RA 1977 Sequential stages of human T lymphocyte differentiation. PNAS 74 3414-3418.

Ueda HR, Chen W, Adachi A, Wakamatsu H, Hayashi S, Takasugi T, Nagano M, Nakahama K, Suzuki Y, Sugano S et al. 2002 A transcription factor response element for gene expression during circadian night. Nature $\mathbf{4 1 8}$ 534-539.

Ueda HR, Hayashi S, Chen W, Sano M, Machida M, Shigeyoshi Y, Iino M \& Hashimoto S 2005 System-level identification of transcriptional circuits underlying mammalian circadian clocks. Nature Genetics 37 187-192.

Wijnen H \& Young MW 2006 Interplay of circadian clocks and metabolic rhythms. Annual Review of Genetics 40 409-448.

Yamamoto T, Nakahata Y, Soma H, Akashi M, Mamine T \& Takumi T 2004 Transcriptional oscillation of canonical clock genes in mouse peripheral tissues. BMC Molecular Biology 518.

Yamazaki S, Numano R, Abe M, Hida A, Takahashi R, Ueda M, Block GD, Sakaki Y, Menaker M \& Tei H 2000 Resetting central and peripheral circadian oscillators in transgenic rats. Science 288 682-685.

Yoo SH, Yamazaki S, Lowrey PL, Shimomura K, Ko CH, Buhr ED, Siepka SM, Hong HK, Oh WJ, Yoo OJ et al. 2004 PERIOD2::LUCIFERASE real-time reporting of circadian dynamics reveals persistent circadian oscillations in mouse peripheral tissues. PNAS 101 5339-5346.

Zvonic S, Ptitsyn AA, Conrad SA, Scott LK, Floyd ZE, Kilroy G, Wu X, Goh BC, Mynatt RL \& Gimble JM 2006 Characterization of peripheral circadian clocks in adipose tissues. Diabetes 55 962-970.

Received in final form 13 March 2007

Accepted 17 March 2007

Made available online as an Accepted Preprint 22 March 2007 